\title{
Проблемы создания гибридного висмут-эрбиевого волоконного лазера
}

\author{
В.М. Парамонов", М.И. Беловолов, С.А. Васильев, М.М. Беловолов, Е.М. Дианов
}

Научный центр волоконной оптики РАН

*E-mail: vparam@fo.gpi.ru

Данная работа суммирует на настоящий момент времени экспериментальный опыт и данные по реализации волоконных лазеров в НЦВО РАН на основе световодов, легированных висмутом, генерирующих в области максимумов основных полос люминесценции около 1,4 мкм и 1,7 мкм, а таке известные данные по эрбиевым волоконным лазерам около длин волн 1,55 мкм, с целью создания волоконной конструкции или единой волоконной среды с солегированием Bi-Er, которая позволила бы реализовать эффективную лазерную генерацию в широкой полосе непрерывной перестройки от 1,3 мкм до 1,8 мкм в одной конструкции прибора, желательно без пропусков диапазонов длин волн и выровненной амплитудной характеристикой мощности генерации. Создание такого широко перестраиваемого лазера может быть полезным для новых применений в волоконном приборостроении, при опросе многих волоконных датчиков с мультиплексированием по длинам волн, в медицине и др. Предполагается, что при решении проблем широко перестраиваемого волоконного лазера будут созданы одномодовые волоконные световоды с оптимальными концентрациями активных солегирующих примесей, подобраны и оптимизированы все основные элементы волоконных лазерных схем, волоконные мультиплексоры, длины волн накачки, фильтрации и селекции, а также волоконных устройств ввода-вывода сигналов для реализации широкополосного усиления DWDM- сигналов для систем коммуникаций.

K настоящему времени хотя и имеются данные по реализации оптического усиления и лазерной генерации в широком диапазоне длин волн от 1.1 до 1.8 мкм, разработаны и исследованы схемы непрерывно перестраиваемых висмутовых волоконных лазеров в отдельных полосах длин волн генерации $1366-1507$ нм [1] и 1654 - 1794 нм [2]. Созданы и испытаны первые висмутовые волоконнооптические усилители для спектральной области 1600 - 1800 нм [3]. Между указанными диапазонами располагается полоса оптической активности ионов $\mathrm{Er}^{3+}$ около 1,55 мкм, которая рассматривается как полоса для «сшивки» спектров в единую широкую полосу перестройки лазерной генерации. В качестве спектрально селективного устройства для перестройки по длинам волн и вывода мощности генерации используется голографическая дифракционная решетка на поворотном столике с приводом, а для выравнивания выходных сигналов по амплитуде используются длиннопериодные волоконные решетки. Полоса оптической активности висмута в кварцевом стекле оптического волокна в зависимости от добавок примеси алюминия, фосфора или германия допускает ощутимые смещения краев полос, что в сочетании с уровнем накачки позволяет несколько смещать края рабочих диапазонов длин волн генерации и оптического усиления и может быть использовано для сопряжения схем по диапазонам рабочих длин волн генерации.

На данном этапе мы допускаем разную реализацию волоконных схем висмутовых и эрбиевых волоконных широко-перестраиваемых лазеров, 
работающих раздельно по диапазонам длин волн, которые могут быть объединены в гибридную конструкцию.

На рисунках 1 и 2 показаны разработанные и исследованные в работах [1] и [2] схемы непрерывно перестраиваемых висмутовых лазеров в диапазонах 1,35 1.51 мкм и $1,65-1,80$ мкм, соответственно.

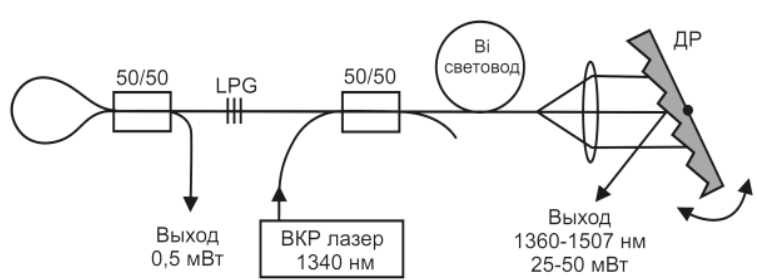

Рис.1. Схема непрерывно перестраиваемого висмутового волоконного лазера для диапазона длин волн $1,36-1,51$ мкм.

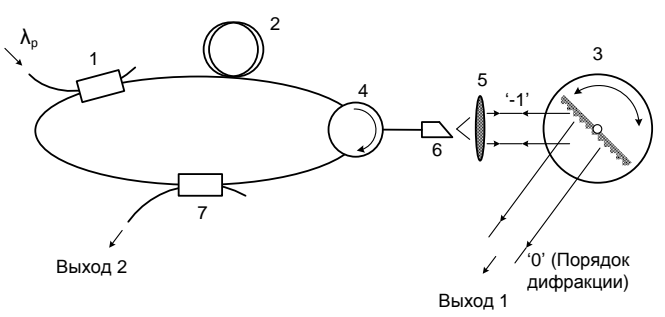

Рис.2. Схема непрерывно перестраиваемого висмутового волоконно лазера кольцевой геометрии для диапазона длин волн $1,65-$ 1,8 мкм.

Для работы параллельной схемы разделения и объединения надо будет применять волоконно-оптические спектральные мультиплексоры и демультиплексоры, что увеличит габариты всего устройства. В этой связи возникает задача разработки и исследования одного волоконного световода, солегированного ионами эрбия $\mathrm{Er}^{3+}$ и активных центров висмута.

На рис.3 приведены возможные схемы комбинированных волоконных систем для оптического усиления и лазерной генерации. На рис.4 показаны спектры люминесценции образца одномодового волоконного световода, солегированного ионами $\mathrm{Er}^{3+}$ и активными висмутовыми центрами, при разных уровнях накачки при наблюдении люминесценции назад.

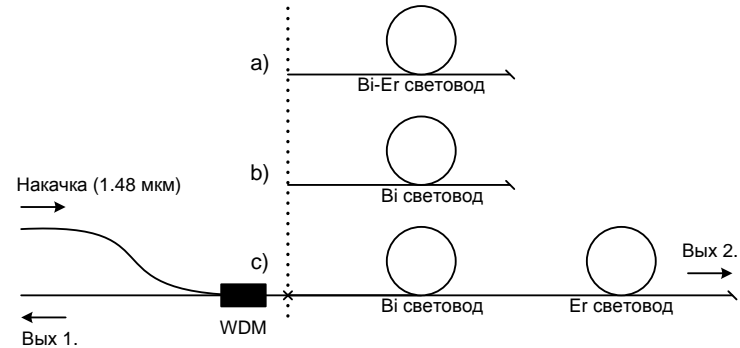

Рис.3. Возможные схемы комбинированных Вi$\mathrm{Er}$ волоконных систем для лазеров.

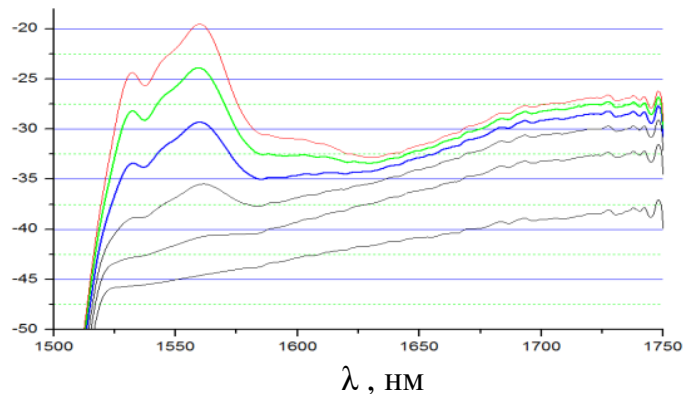

Рис.4. Комбинированный спектр люминесценции солегированного $\mathrm{Bi}-\mathrm{Er}$ одномодового волокна при разных мощностях накачки от 100 мВт до 250 мВт на 1,48 мкм.

Рисунки 3 и 4 частично поясняют, что главными проблемами при создании комбинированных висмут-эрбиевых лазеров будут являться подбор и оптимизация составов матриц кварцевого стекла одномодовой сердцевины волокна для сопряжения рабочих спектральных диапазонов, уровня легирования активными примесями и топологии волоконной схемы лазера с разделением активных участков и направления ввода излучения накачки.

\section{Литература}

[1] М.Парамонов, М.И.Беловолов, и др., Квантовая электроника, 46, 1068 - 1093 (2016)

[2] В.М.Парамонов, С.А.Васильев, и др., Квантовая электроника, 47, 1091 - 1070 (2017)

[3] С.В.Фирстов, С.А.Алышев м др., Квантовая электроника, 45, 1083-1085 (20015) 